and zoological interest. It is exceedingly impressive to see an extensive archipelago, of most recent origin, inhabited by creatures so different from any known in other parts of the world. Here we have a positive limit to the length of time that may be granted for the transformation of these animals, if they are in any way derived from athers dwelling in different parts of the world. The Galapagos are so recent that some of these islands are barely covered with the most scanty vegetation, itself peculiar to these islands; some parts of their surface are entirely bare, and a great many of the crateri and lava streams are so fresh that the atmospheric arents have not yet made an impression upon them. Their agent does not, therefore, go back to earlier geological periods ; they belong to our time, geologically speaking. Whence then do their inhabitants come from - animals as well as plants? If descended from some other type, belonging to some neighbouring land, then it does not require such unspeakably long periods for the transformation of species as the modern advocates of transmutation claim; and the mystery of change, with such marked and characteristic differences between existing species, is only increased and brought to a level with that of creation. If they are autochthones, from what germs did they start into existence? I think that careful observers, in view of these facis, will have to acknowledge that out science is not yet ripe for a fair discussion of the origin of orgrinised beings.

Our stay in Panama has allowed us to make very extensive collections in the Bay and across the Isthmus. I was surprised to find so little difference in the character of the fiora and of the terrestrial fauna between the two oceans. Marked peculiarities are only to be found amons the marine animals, and even among them tho American character of the Atlantic and Pacific marine fauna is unmistakable; we are not surrounded by animals recalling by their peculiarities the many groups of islands of the Pacific. I expect that our visit in Acapulco will confirm these inpressions.

L. AGASSiZ

\section{CAPTAIN HALL'S ARCTIC EXPEDITION}

$\mathrm{E}$. Washington Chronicle of August 26 contains the following interesting account of the progress and position of this important expedition :- "The Navy Department has received later despatches from Captain Hall, by the way of Tydskland and Copenhagen, completing his official record up to the moment of final departure from North Greenland. These despatches, which are quite full, bear date off Tossak, Tussuissuk, N. lat. $73^{\circ} 21^{\prime}$, W.long. $56^{\circ} 5^{\prime}$, August 24,1871 , and are, therefore, only four days later than Hall's Upper Navik despatch, August 20, $187 \mathrm{I}$, which reached the department within three months by the way of Copenhagen. The explanation of this long delay in transitu is that there is no regular communication between Denmark and these far-off colonies but once a year. Hall's Upper Navik despatches were timed to reach the Danish brig just then sailing, and this present letter sent back by native pilots, as he notes in concluding, may have had near a year's detention in Disco. It seern; to have reached the American Minister at Copenhagen about July 3o. Although thus divested of any special value as news, the present despatch is of much intrinsic interest. All on board the Polaris, officers, scientific corps, and men, were well and in excellent spirits. The seagoing qualities of the vessel had been tested and found adinirable; the engines and machinery were in perfect working order, coal and rosin in good supply, and the ship's crew abundantly provisioned. For the long Arctic night before them they had books, games, instrumental music, \&c. - in a word, everything that the thoughtful care of the department could supply, or letters of credit at Newfoundland and in Greenland furnish, had been laid in to complete their outfit, and of all this Captain Hall makes characteristic and thankful acknowledgments. Governor Elberg, of the Navik district, had accompanied the Polaris as far as Tossait, the extremest northerly limits of Danish jurisdiction as well as of civilised life, and was to the last insment assiduous in his exertions to further the interests of the expedition. Mainly througr his co-operation $\mathrm{Ha}$ al was forturate enough at Tossak to make up his complement of Esquimaux dogs-sixty strong, healthy animals -a matter of almost vital importance. He likewise laid in a large supply of dog food, and considerably augnented his stock of reindeer-furs, sealskins, \&c., for the adventurous voyage. At Upper Navik the expadition had shipped Hans Christian, a famous native hunter and dor-driver, with his wife and three children. Jensen, the Dane, who was under promise to join the expedition at Tossak, backed out at the last moment. Govanor Elberg, of whose many kindnesses Hall speaks with full heart, awaited at Tossak the return of the native pilots, bearing this despatch to him, and it closes with the prow of the Polaris northward in the early morning of August 24, with a complete roster of all on board, thirty-three souls, and a fervent, hopeful prayer for success. It will be remembered that Captain Hall's previous despatches speal of his good fortune in meeting at Holsteinburg the returning Swedish expedition, and that the commander, Baron van Otter, kindly furnished hin copies of log, decp-sea soundings, \&c., assuring him that the season was more than usually favourable, and extremely wide iceberg-channels, \&c. Of the same purport was the information received of Governor Rodolph, thirty years resident in North Greenland, who declared the year to be nore favounable for any northern voyzge than many years agone or to come. Acting on this ir. formation, and under discretionary power vested in him by the Navy Deparment, Cantain Hall had abandoned the Jones's Sound ronte, and had decided before he left Uprer Navik that after stopping at Tossak he would cross Merrile Bay to Cape Dudley Digres, and from that point steam direct to Snith's Sound, thence make all possible attampts to find a passage on the west side of the Sound from Cape Isabella up to Kennedy Channels, wintering there probably in about the same latitude or a little higher than Kane's winter quarters, and thence on and up to the North Pole. The letter published in the Now York Times, April 25, purporting to narrate a disaster to the Polcris and her rivum last February to Disco, was a carawt. Not one word of it has ever been credited at the Navy Department. It is not believed that any disaster has overtaken the Expedition, or that any ground for apprehension exists."

\section{THE BLIND FISHES OF THE MAMMOTH CAVE AND THEIR ALLIES*}

THE Amolyopsis spelceus undoubtedly has quite an extensive distribution, probably existing in all the subterranean rivers that flow through the great limestone region underlying the Carboniferous rocks in the central portion of the United Staies. Prof. Cope obtained specimens from the Wyandotte Cave and from wells in its vicinity, and in the Museum of Comparative Zoology at Cambridge there is a specimen labelled "from a well near Lost River, Orange Co., Ind.," which, with those from the Wyandotte Cave, is conciusive evidence of its being found on the northern side of the Ohio $t$ as well as on the southern, in the rivers of the Mammoth Cave. I have been able to examine a number of specimens from the Mammoth Cave, and have carefully compared with them the one from the well in Orange Co., Ind., and find that the specific characters are remarkably constant.

* Reprinted from the America" Naturalist, a sequel to "The Blind Crustacea of the Mammoth Cave." See NATURE, vol. v. pp. $445,484$.
+ I have also been intormed by Mr Holmes of Lansing, Mich, that $t$ I have also been intormed by $\mathrm{Mr}$ Holmes of $\mathrm{L}$
blind fishes have been drawn out of wells in Michigan. 